Original Research Paper

\title{
Preparation of $\mathrm{LiCoMnO}_{4}$ Assisted by Hydrothermal Approach and its Electrochemical Performance
}

\author{
${ }^{1}$ Meilin You, ${ }^{1}$ Xingkang Huang, ${ }^{1}$ Min Lin, ${ }^{1}$ Qingsong Tong, ${ }^{1}$ Xiuhua Li, ${ }^{1}$ Ying Ruan and ${ }^{2}$ Yong Yang \\ ${ }^{I}$ Department of Chemistry, Fujian Normal University, Fuzhou, China \\ ${ }^{2}$ State Key Laboratory for Physical Chemistry of Solid Surfaces and Department of Chemistry, \\ College of Chemistry and Chemical Engineering, Xiamen University, Xiamen, China
}

\author{
Article history \\ Received: 26-09-2015 \\ Revised: 14-11-2015 \\ Accepted: 21-05-2016 \\ Corresponding Author: \\ Xingkang Huang and \\ Qingsong Tong \\ Department of Chemistry, Fujian \\ Normal University, Fuzhou, China \\ Email: xkhuang@126.com and \\ qstong_3503@fjnu.edu.cn \\ Yong Yang \\ State Key Laboratory for Physical \\ Chemistry of Solid Surfaces and \\ Department of Chemistry, \\ Chemical Engineering, Xiamen \\ University, Xiamen, China \\ Email: yyang@xmu.edu.cn
}

\begin{abstract}
LiCoMnO}_{4}$ materials have been synthesized via a hydrothermal approach followed by a post-annealing process. Pure phase of $\mathrm{LiCoMnO}_{4}$ is unable to form under hydrothermal conditions; however, high quality of pure $\mathrm{LiCoMnO}_{4}$ was achieved after annealing the hydrothermal products. The concentration of $\mathrm{LiOH}$ and the post-annealing temperature are the crucial factors to form $\mathrm{LiCoMnO}_{4}$. Without post-annealing process, the highest contents of $\mathrm{LiCoMnO}_{4}$ in the hydrothermal products are less than $50 \%$ (e.g., in the presence of 1.2-1.35 M LiOH); in contrast, in the cases of 1.35-1.4 M LiOH, almost pure phase of $\mathrm{LiCoMnO}_{4}$ has been achieved successfully after annealing the hydrothermal precursors at $750^{\circ} \mathrm{C}$. The asprepared sample in the presence of $1.35 \mathrm{M} \mathrm{LiOH}$, after annealed at $750^{\circ} \mathrm{C}$, exhibits a capacity of $91.6 \mathrm{mAh} \mathrm{g}^{-1}$.
\end{abstract}

Keywords: Lithium Manganese Oxide, 5 V Spinel, Lithium-Ion Battery, Cathode

\section{Introduction}

$\mathrm{LiCoMnO}_{4}$ possesses a spinel structure similar to $\mathrm{LiMn}_{2} \mathrm{O}_{4}$ and a high potential of ca. $5.0 \mathrm{~V}$ versus lithium. Compared to another $5 \mathrm{~V}$ spinel, $\mathrm{LiNi}_{0.5} \mathrm{Mn}_{1.5} \mathrm{O}_{4}$ which has been investigated extensively (Li et al., 2007; Santhanam and Rambabu, 2010; Yang et al., 2011; Zhong et al., 2011; Cabana et al., 2012; Mao et al., 2012; Liu et al., 2012), $\mathrm{LiCoMnO}_{4}$ is relatively new material. $\mathrm{LiNi}_{0.5} \mathrm{Mn}_{1.5} \mathrm{O}_{4}$ is usually charged to cutoff voltages of 4.9-5.0 V (Liu et al., 2012; Shin et al., 2012; Yi and $\mathrm{Hu}, 2007$; Huang et al., 2011) while $\mathrm{LiCoMnO}_{4}$ has to be charged to $5.3 \mathrm{~V}$ due to its two charging plateaus at 5.2 and $4.9 \mathrm{~V}$ (Kawai et al., 1999; 1998; Huang et al., 2012; Hu et al., 2013; 2014; Kuwata et al., 2014). The main obstacle to practice $\mathrm{LiCoMnO}_{4}$ is the requirement of electrolytes tolerant to high voltage above $5.0 \mathrm{~V}$. Recent development of electrolytes such as reducing the contents of impurities and exploring new electrolytes (Markevich et al., 2006; Abouimrane et al., 2009) and additives (Lee et al., 2007; Xu et al., 2012;
Abouimrane et al., 2013), offers a new chance for the practical application of $\mathrm{LiCoMnO}_{4}$ as cathode materials for lithium-ion batteries. $\mathrm{LiCoMnO}_{4}$ has been synthesized usually by solid-state reactions. For example, a $\mathrm{LiCoMnO}_{4}$ was obtained by heating the stoichiometric mixtures of dried $\mathrm{Li}_{2} \mathrm{CO}_{3}, \mathrm{CoO}$ and $\mathrm{MnCO}_{3}$ (Kawai et al., 1998). Our group recently has prepared $\mathrm{LiCoMnO}_{4}$ via a sol-gel method (Huang et al., 2012). However, the synthesis of $\mathrm{LiCoMnO}_{4}$ by a hydrothermal method has not reported, to the best of our knowledge. In this study, we obtained $\mathrm{LiCoMnO}_{4}$ via the hydrothermal approach and investigated the effects of post-annealing on the hydrothermal products.

\section{Experimental}

About $0.005 \mathrm{~mol} \mathrm{MnSO}_{4} \cdot \mathrm{H}_{2} \mathrm{O}(\geq 99 \%), 0.005 \mathrm{~mol}$ $\mathrm{CoSO}_{4} \cdot 7 \mathrm{H}_{2} \mathrm{O}(\geq 98.5 \%)$ and $0.0075 \mathrm{~mol}\left(\mathrm{NH}_{4}\right)_{2} \mathrm{~S}_{2} \mathrm{O}_{8}$ were dissolved in $20 \mathrm{~mL}$ deionized water solution in a $100 \mathrm{~mL}$ Teflon container, where $\mathrm{LiOH} \cdot \mathrm{H}_{2} \mathrm{O}(\geq 98 \%)$ dissolved in $30 \mathrm{~mL}$ deionized water was added 
dropwise. The Teflon container was then transferred to a stainless steel autoclave, sealed and heated at $220^{\circ} \mathrm{C}$ for $22 \mathrm{~h}$. The resulting precipitate was separated from the solvents by filtration and then washed with deionized water. The sample was obtained after drying at $120^{\circ} \mathrm{C}$ for $24 \mathrm{~h}$. To obtain the optimized conditions to synthesize $\mathrm{LiCoMnO}_{4}, 0.9-1.5 \mathrm{M} \mathrm{LiOH}$ were employed, where the concentration was calculated based the $50 \mathrm{~mL}$ solution in total. The hydrothermal products were heat-treated at $550-750^{\circ} \mathrm{C}$.

The as-prepared samples were examined by powder X-Ray Diffraction (XRD) analysis, performed using a PANalytical X'Pert diffractometer with $\mathrm{Cu} \mathrm{K} \alpha$ radiation (Philips). The XRD results were analyzed using an X'pert HighScore and X'pert Plus to obtain the crystal parameters of the samples. Morphology observation was studied by Scanning Electron Microscopy (SEM) performed with a Zeiss LEO1530.

Electrode fabrication and coin cell assembly were carried out as described in our previous report (Huang et al., 2009). In brief, the active material was mixed with $10 \mathrm{wt} \%$ acetylene black and $10 \mathrm{wt} \%$ binder (PVDF) and then ground by ball milling. The cathode was obtained by pressing the mixture onto a piece of aluminum foil followed by drying in a vacuum oven at $120^{\circ} \mathrm{C}$ for $2 \mathrm{~h}$. The coin cells were fabricated with the prepared cathode, lithium anode, Celgard 2400 polypropylene separator and $1 \mathrm{M} \mathrm{LPF}_{6}$ in ethylene carbonate/dimethyl carbonate $(1: 1 \mathrm{v} / \mathrm{v})$ electrolyte. Cell testing was carried out at a constant current density of $140 \mathrm{~mA} \mathrm{~g}^{-1}$ at $27^{\circ} \mathrm{C}$ using a Land battery test system (Wuhan, China).

\section{Results and Discussion}

Figure 1 shows the XRD patterns of hydrothermal products in the presence of various $\mathrm{LiOH}$ concentrations. At low $\mathrm{LiOH}$ concentration such as 0.9$1.1 \mathrm{M}$, the as-obtained samples consist of $\mathrm{LiMn}_{2} \mathrm{O}_{4}$, $\mathrm{Co}_{3} \mathrm{O}_{4}$ and $\mathrm{Mn}_{3} \mathrm{O}_{4}$. The peaks located at between 29 and $34^{\circ}$ should belong to Co-doped Hausmannite, namely $\mathrm{Co}_{\mathrm{x}} \mathrm{Mn}_{3-\mathrm{x}} \mathrm{O}_{4}$. The XRD peaks of $\mathrm{Co}_{3} \mathrm{O}_{4}$ are significantly overlapped with those of $\mathrm{LiMn}_{2} \mathrm{O}_{4}$; however, the intensity of the peak at ca. $36.5^{\circ}$ is greater than that at ca. $18.8^{\circ}$ (Fig. 1a and $1 \mathrm{~b}$ ), which suggests the existence of $\mathrm{Co}_{3} \mathrm{O}_{4}$. When $\mathrm{LiOH}$ concentration is higher than $1.2 \mathrm{M}$, these peaks over 29-34 ${ }^{\circ}$ disappeared, accompanied by decrease of the peak at $36.5^{\circ}$ (Fig. 1c). These suggest that the contents of the impurities of $\mathrm{Co}_{3} \mathrm{O}_{4}$ and $\mathrm{Co}_{\mathrm{x}} \mathrm{Mn}_{3-\mathrm{x}} \mathrm{O}_{4}$ decreased. When the concentration of $\mathrm{LiOH}$ increased to $1.8 \mathrm{M}$, the intensity of the peak at ca. $44.5^{\circ}$ turned higher than that at ca. $36.5^{\circ}$, which suggests the formation of $\mathrm{Li}_{2} \mathrm{MnO}_{3}$. As a result, spinel $\mathrm{LiMn}_{2} \mathrm{O}_{4}$ phase could be synthesized when the $\mathrm{LiOH}$ concentrations were employed in the range of 1.2-1.35 $\mathrm{M}$ in our experimental conditions. It is also notable that the peaks of the as-prepared $\mathrm{LiMn}_{2} \mathrm{O}_{4}$ shifted significantly toward high $2 \theta$ angle, which is due to the doping of cobalt ions in the structure of $\mathrm{LiMn}_{2} \mathrm{O}_{4}$ (Huang et al., 2012).

However, due to the similar structure between $\mathrm{LiMn}_{2} \mathrm{O}_{4}$ and $\mathrm{LiCoMnO}_{4}$, it is difficult to distinguish them from the XRD patterns. Therefore, we examined the electrochemical performances of these hydrothermal samples. As shown in Fig. 2, when $\mathrm{LiOH}$ concentration is $0.9 \mathrm{M}$, it only shows a plateau at ca. $3.8 \mathrm{~V}$. The plateau of $\mathrm{LiCoMnO}_{4}$ (above $4.2 \mathrm{~V}$ ) started to develop with the increase of $\mathrm{LiOH}$ concentration. The capacity above $4.2 \mathrm{~V}$ realted to $\mathrm{LiCoMnO}_{4}$ reached the highest value at the $\mathrm{LiOH}$ concentration of $0.5 \mathrm{M}$. Beyond $0.5 \mathrm{M} \mathrm{LiOH}$ employed, $\mathrm{Li}_{2} \mathrm{MnO}_{3}$ phase was developed; as shown in Fig. 2 (above), when $1.8 \mathrm{M} \mathrm{LiOH}$ employed, the obtained sample presents a typical charge/discharge curves of $\mathrm{Li}_{2} \mathrm{MnO}_{3}$, exhibiting a discharge curve without remarkable plateau (Huang et al., 2009; Yue et al., 2008). This agrees well with the XRD result that the sample obtained in the presence of $1.8 \mathrm{M} \mathrm{LiOH}$ is composed of $\mathrm{Li}_{2} \mathrm{MnO}_{3}$ phase (Fig. 1f). This sample delivered a capacity of $167.0 \mathrm{mAh} \mathrm{g}^{-1}$ at the current density of $140 \mathrm{mAh} \mathrm{g}^{-1}$, which is, however, beyond the interest of this study on $5 \mathrm{~V}$ spinel materials.

We obtained almost pure phase of $\mathrm{LiNi}_{0.5} \mathrm{Mn}_{1.5} \mathrm{O}_{4}$ by the hydrothermal method in our previous report (Huang et al., 2011). In contrast, the hydrothermal approach to obtain pure phase of $\mathrm{LiCoMnO}_{4}$ are still unsuccessful at this stage, which is evidenced by the fact that the discharge capacities of the samples obtained in the presence of 1.2-1.3 $\mathrm{M} \mathrm{LiOH}$ are 70-80 $\mathrm{mAh} \mathrm{g}^{-1}$ with ca. $35 \mathrm{mAh} \mathrm{g}^{-1}$ located above $4.2 \mathrm{~V}$. There are still some impurities such as $\mathrm{LiMn}_{2} \mathrm{O}_{4}$ and $\mathrm{Li}_{2} \mathrm{MnO}_{3}$ in these hydrothermal products. We then decided to employ post-annealing to improve the phase content of $\mathrm{LiCoMnO}_{4}$.

As shown in Fig. 3, annealing hydrothermal products at $550^{\circ} \mathrm{C}$ resulted in broad XRD peaks with low intensities, while the peaks turned narrower and stronger as the annealing temperature increases. However, it seems no apparent difference between the XRD patterns of the samples obtained from various LiOH concentrations (1.1-1.4 M). Therefore, we compared these patterns by analyzing the (110) peak positions at ca. $19^{\circ}$ and the Full-Width-at-HalfMaximum (FWHM) of these peaks as shown in Table 1. The FWHM values decreases with the annealing temperatures and with the increase of $\mathrm{LiOH}$ concentrations employed during the hydrothermal 
reaction. Actually, the particle sizes of samples increased with the annealing temperatures as shown in Fig. 4. The primary particle size of the as-synthesized hydrothermal precursor (at $1.35 \mathrm{M} \mathrm{LiOH}$ ) is ca. $30 \mathrm{~nm}$ (Fig. 4a); after annealing at $550^{\circ} \mathrm{C}$, some crystal particles developed (Fig. 4b). When annealing at $750^{\circ} \mathrm{C}$, the obtained sample shows well-defined crystals in 80-150 $\mathrm{nm}$ size range (Fig. 4c). On the other hand, at the same annealing temperatures, the higher the $\mathrm{LiOH}$ concentration, the higher angle the peak at the (110) plane moves towards as shown in Table 1. The parameters $a$ of such samples were also calculated by assuming the pure phase of $\mathrm{LiCoMnO}_{4}$. Generally, the higher $\mathrm{LiOH}$ concentration favors the smaller $a$ value. Figure 5 show charge/discharge curves of annealed samples from the precursor prepared in the presence of $1.1 \mathrm{M} \mathrm{LiOH}$. As shown in Fig. 5a, the samples after annealing at $550^{\circ} \mathrm{C}$ delivered an initial capacity of $54.5 \mathrm{mAh} \mathrm{g}^{-1}$ at a current density of $140 \mathrm{~mA} \mathrm{~g}^{-1}$ and decayed to 45.2 $\mathrm{mAh} \mathrm{g}^{-1}$ after 5 cycles. There are two voltage plateaus at ca. 4.5 and $3.7 \mathrm{~V}$, corresponding to the electrochemical pairs of $\mathrm{Co}(\mathrm{IV}) / \mathrm{Co}(\mathrm{III})$ and $\mathrm{Mn}(\mathrm{IV}) / \mathrm{Mn}(\mathrm{III})$, respectively, accompanied with insertion of $\mathrm{Li}^{+}$into the tetragonal $8 \mathrm{a}$ sites in the spinel structure. When the precursor was annealed at $650^{\circ} \mathrm{C}$, the resulting product delivered $79.3 \mathrm{mAh} \mathrm{g}^{-1}$ until the voltage cutoff of $3.0 \mathrm{~V}$ and decayed to 67.9 $\mathrm{mAh} \mathrm{g}^{-1}$ at the fifth cycle. If the voltage cutoff decreased to $2.0 \mathrm{~V}$, the higher capacity of $164.0 \mathrm{mAh}$ $\mathrm{g}^{-1}$ was achieved with a new developed voltage plateau at ca. $2.5 \mathrm{~V}$ which is associated with Mn (IV) changed to $\mathrm{Mn}$ (III) accompanied with $\mathrm{Li}^{+}$entering the octahedral $16 \mathrm{c}$ sites in the spinel structure. When the annealing temperature increased to $750^{\circ} \mathrm{C}$, the asobtained sample exhibits an initial capacity of 71.4 $\mathrm{mAh} \mathrm{g}^{-1}$ and no obvious degeneration within 10 cycles as shown in Fig. 5c.

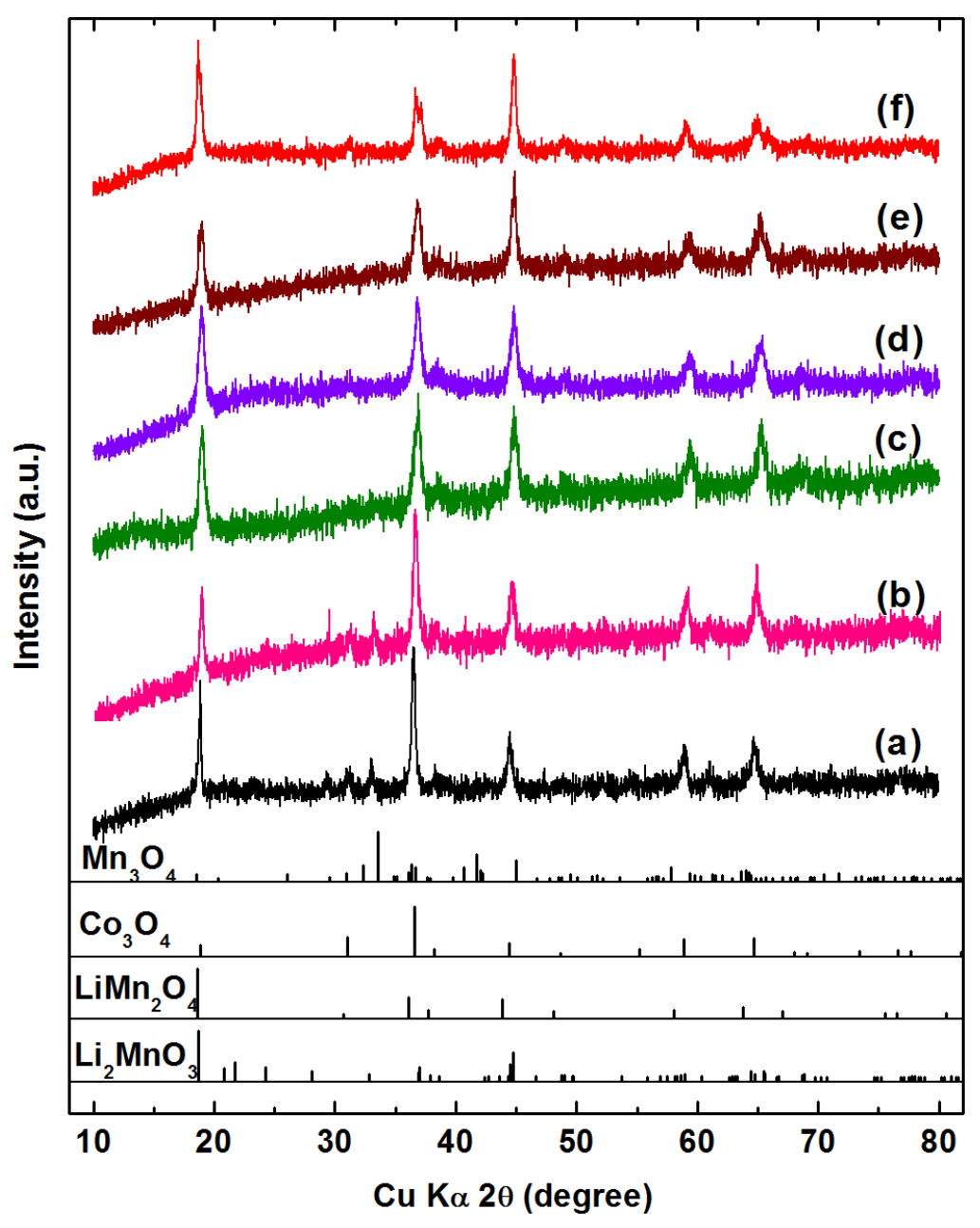

Fig. 1. XRD patterns of samples in the presence of (a) 0.1 , (b) 0.3 , (c) 0.4 , (d) 0.5 , (e) 0.55 and (f) $1.8 \mathrm{M} \mathrm{LiOH}$ at $220^{\circ} \mathrm{C}$. The JCPDS numbers for $\mathrm{Mn}_{3} \mathrm{O}_{4}, \mathrm{Co}_{3} \mathrm{O}_{4}, \mathrm{LiMn}_{2} \mathrm{O}_{4}$ and $\mathrm{Li}_{2} \mathrm{MnO}_{3}$ are 80-382, 80-1536, 89-8321 and 84-1634, respectively 


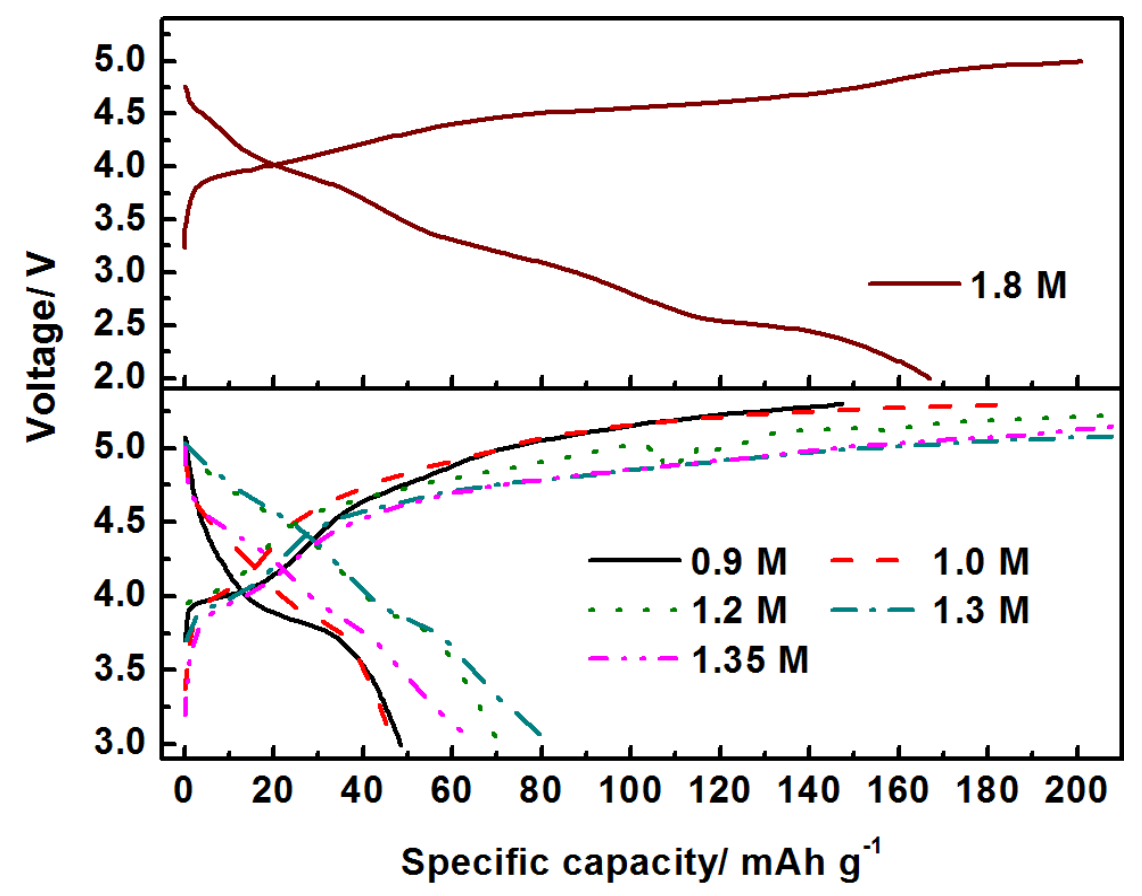

Fig. 2. Charge/discharge curves of hydrothermal products synthesized at various LiOH concentrations. The cutoff voltages were limited between 5.3 and $3.0 \mathrm{~V}$ except the case of $1.8 \mathrm{M} \mathrm{LiOH}$ which was limited between 4.8-2.0 V

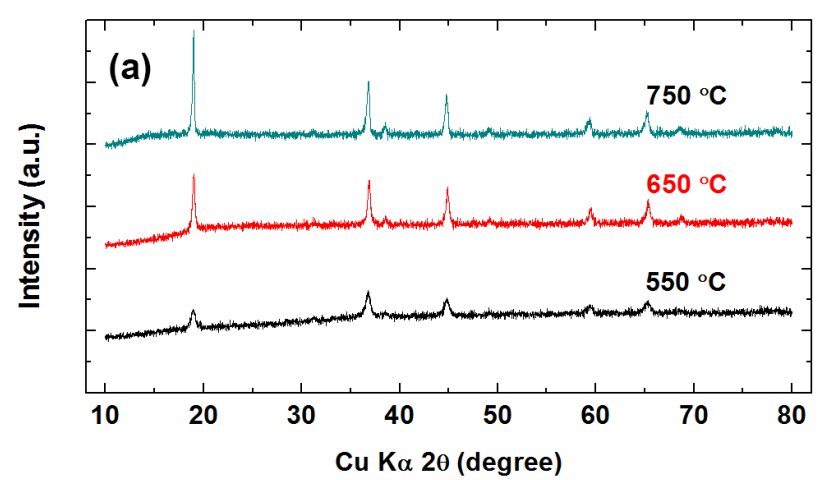

(a)

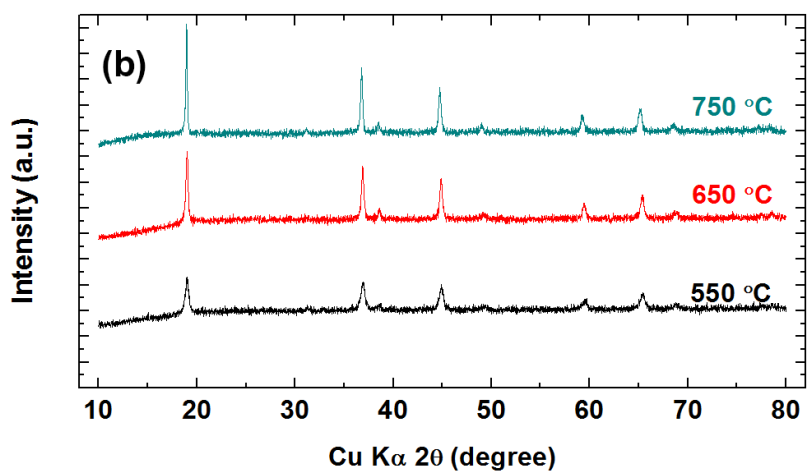

(b)

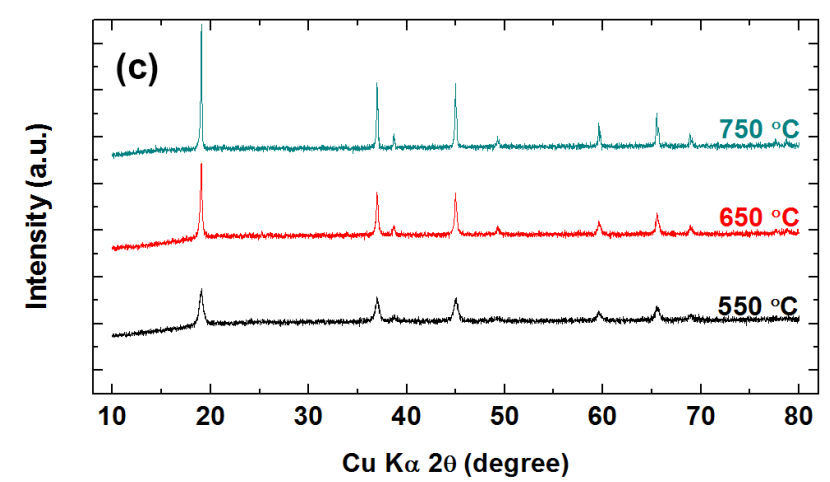

(c)

Fig. 3. Effect of post-annealing on the structures of hydrothermal precursors in the presence of (a) 1.1 , (b) 1.2 and (c) $1.35 \mathrm{M}$ $\mathrm{LiOH}$ 


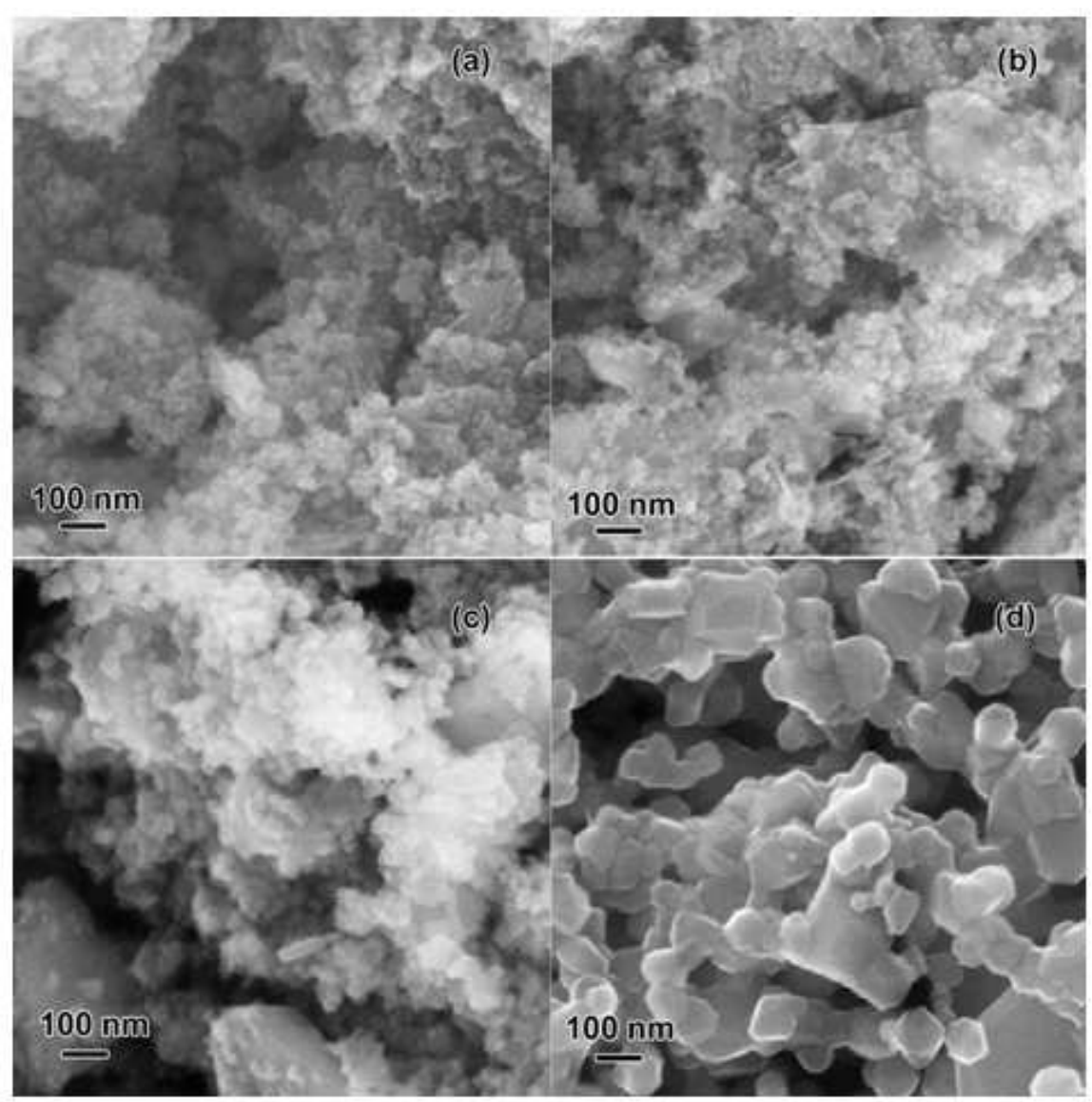

Fig. 4. SEM images of (a) the sample obtained in the presence of $1.35 \mathrm{M} \mathrm{LiOH}$ and its annealed samples at (b) 550 , (c) 650 and (d) $750^{\circ} \mathrm{C}$

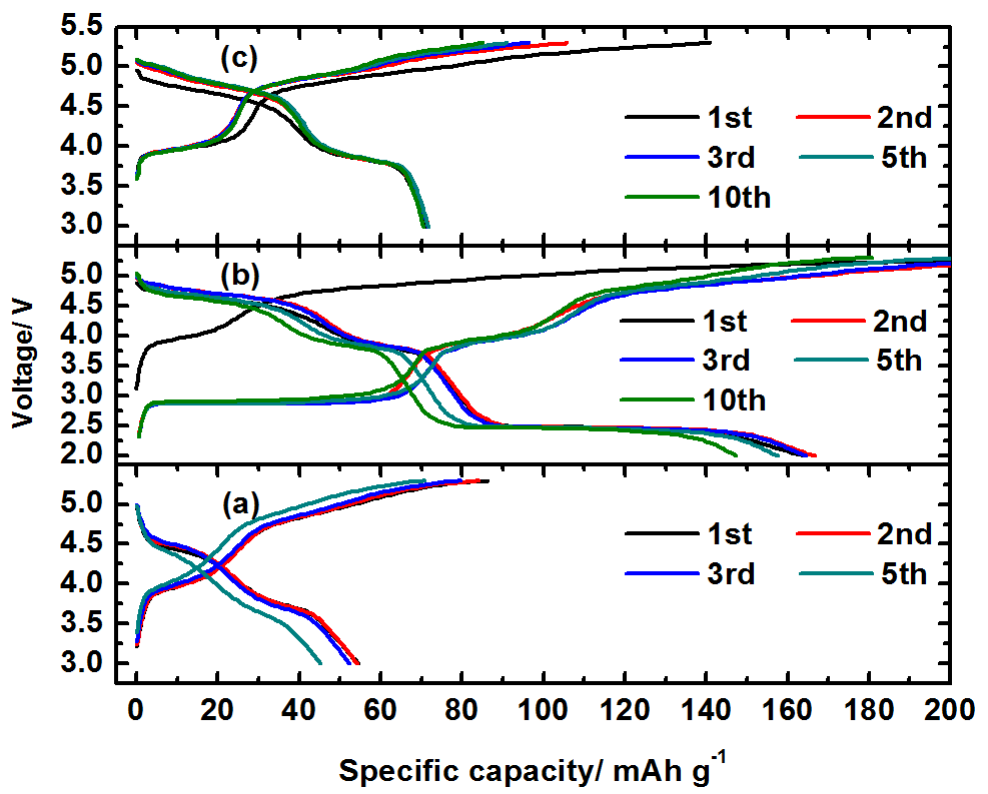

Fig. 5. Charge/discharge curves of samples obtained annealing the precursors in the presence of $1.2 \mathrm{M} \mathrm{LiOH}$ at (a) 550 , 650 and $750^{\circ} \mathrm{C}$ 


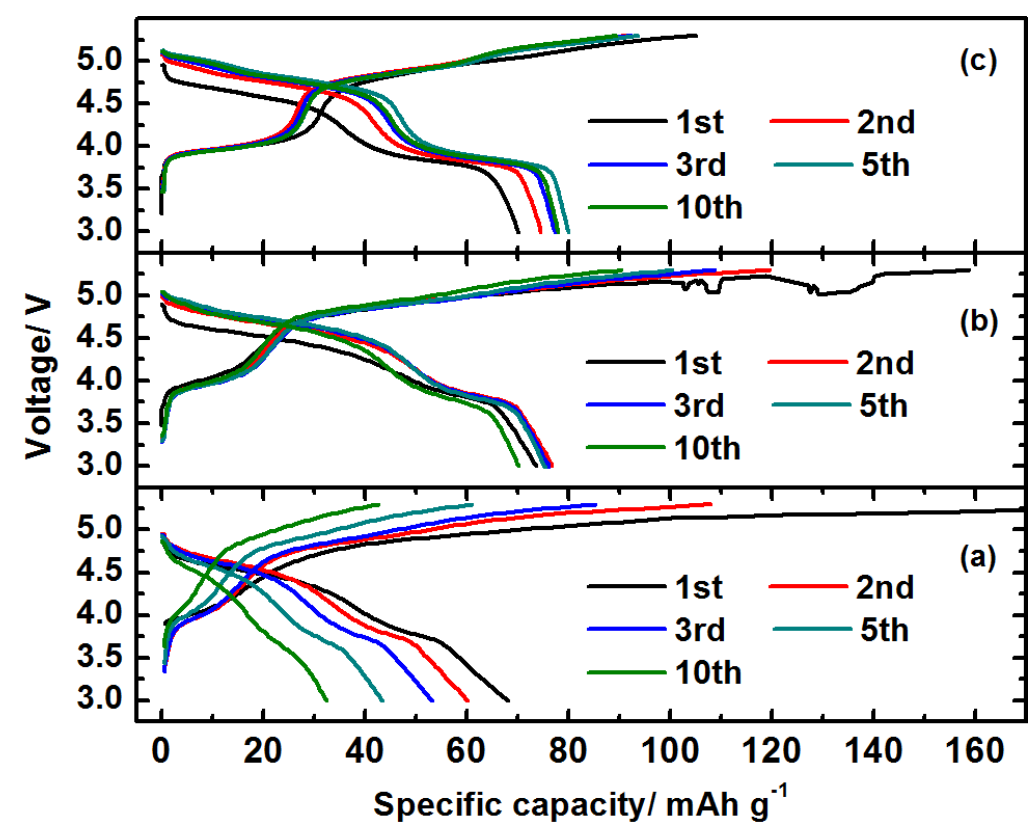

Fig. 6. Charge/discharge curves of samples obtained annealing the precursors in the presence of $1.1 \mathrm{M} \mathrm{LiOH}$ at (a) 550,650 and $750^{\circ} \mathrm{C}$

Table 1. XRD peak positions at the (110) plane of $\mathrm{LiCoMnO}_{4}$ and crystal parameters of the samples by annealing the precursors obtained at various $\mathrm{LiOH}$ concentrations under the hydrothermal reaction

\begin{tabular}{|c|c|c|c|c|}
\hline \multirow[b]{2}{*}{ LiOH conc., $\mathrm{M}$} & \multirow[b]{2}{*}{ Annealing temp., ${ }^{\circ} \mathrm{C}$} & \multicolumn{2}{|c|}{ XRD Peak@(110) } & \multirow[b]{2}{*}{ Parameter $a, \AA$} \\
\hline & & Position, ${ }^{\circ}$ & $\mathrm{FWHM}^{\circ}{ }^{\circ}$ & \\
\hline 1.1 & 550 & 18.93 & 0.460 & $8.081(4)$ \\
\hline 1.1 & 650 & 18.98 & 0.264 & $8.0727(5)$ \\
\hline 1.1 & 750 & 18.95 & 0.188 & $8.090(1)$ \\
\hline 1.2 & 550 & 18.98 & 0.376 & $8.065(2)$ \\
\hline 1.2 & 650 & 18.98 & 0.252 & $8.073(2)$ \\
\hline 1.2 & 750 & 18.94 & 0.178 & $8.0705(9)$ \\
\hline 1.27 & 550 & 19.01 & 0.408 & $8.062(1)$ \\
\hline 1.27 & 650 & 19.01 & 0.282 & $8.059(2)$ \\
\hline 1.27 & 750 & 18.93 & 0.151 & $8.108(1)$ \\
\hline 1.35 & 550 & 19.03 & 0.415 & $8.0490(6)$ \\
\hline 1.35 & 650 & 19.04 & 0.223 & $8.048(1)$ \\
\hline 1.35 & 750 & 19.02 & 0.145 & $8.0527(5)$ \\
\hline 1.4 & 550 & 18.98 & 0.368 & $8.064(2)$ \\
\hline 1.4 & 650 & 19.04 & 0.201 & $8.0487(2)$ \\
\hline 1.4 & 750 & 19.04 & 0.113 & $8.0574(2)$ \\
\hline
\end{tabular}

When the precursor was prepared in the presence of $1.2 \mathrm{M} \mathrm{LiOH}$, its annealed samples depict higher capacities at the $5 \mathrm{~V}$-plateau zones (above $4.2 \mathrm{~V}$ ), i.e., 35.3, 48.6 and $48.5 \mathrm{mAh} \mathrm{g}^{-1}$ for 550,650 and $750^{\circ} \mathrm{C}$, respectively (Fig. 6). On contrast, in the case of $1.35 \mathrm{M}$ $\mathrm{LiOH}$, the samples after annealing at 550, 650 and $750^{\circ} \mathrm{C}$ delivered discharge capacities of 52.2, 75.3 and $91.6 \mathrm{mAh} \mathrm{g}^{-1}$, with $34.1,61.8,79.5 \mathrm{mAh} \mathrm{g}^{-1}$ located at above $4.2 \mathrm{~V}$, corresponding to $65.3,82.1$ and $86.8 \%$ of their total capacities, respectively (Fig. 7). The discharge capacity of the sample obtained at $750{ }^{\circ} \mathrm{C}$ is comparable to those reported in the literature on $\mathrm{LiCoMnO}_{4}$ synthesized by a solid-state reaction (Kawai et al., 1998) or sol-gel method (Huang et al., 2012). Kawai et al. (1998) prepared a $\mathrm{LiCoMnO}_{4}$ by the solid-state reaction, which delivered a discharge capacity of ca. $95 \mathrm{mAh} \mathrm{g}^{-1}$. Huang et al. (2012) employed the sol-gel method to prepared a $\mathrm{LiCo}_{1.09} \mathrm{Mn}_{0.91} \mathrm{O}_{4}$ exhibiting a capacity of $87.1 \mathrm{mAh} \mathrm{g}^{-1}$.

When the employed $\mathrm{LiOH}$ concentration increased to $1.4 \mathrm{M}$, the as-obtained samples behaved like the case in the presence of $1.35 \mathrm{M} \mathrm{LiOH}$ (not shown here). 
Beyond this concentration, e.g., at $1.5 \mathrm{M} \mathrm{LiOH,}$ rocksalt phase of $\mathrm{Li}_{2} \mathrm{MnO}_{3}$ was developed. As shown in Fig. 8, a shoulder peak at ca. $18.7^{\circ}$ that belongs to $\mathrm{Li}_{2} \mathrm{MnO}_{3}$ appeared near the main peak at ca. $19.0^{\circ}$ ascribed to $\mathrm{LiCoMnO}_{4}$. The contents of $\mathrm{Li}_{2} \mathrm{MnO}_{3}$ in samples annealed from the precursor in the presence of $1.5 \mathrm{M} \mathrm{LiOH}$ are $22.8-26.5 \%$, calculated by integrating the XRD peak area at $18.7^{\circ}$ after separating it from the main peak at $19.0^{\circ}$ (Fig. 8). The existence of $\mathrm{Li}_{2} \mathrm{MnO}_{3}$ in these samples is also supported by their discharge profiles as shown in Fig. 9. The voltage cutoffs were extended to $2.0 \mathrm{~V}$ to exhibit the discharge profile of $\mathrm{Li}_{2} \mathrm{MnO}_{3}$. The discharge capacity located at the oblique-line zone of 3.5-2.5 V was ascribed to the contribution of $\mathrm{Li}_{2} \mathrm{MnO}_{3}$ in the samples (Fig. 9). The unmarked voltage plateau is a characteristic of discharge process of $\mathrm{Li}_{2} \mathrm{MnO}_{3}$ materials (Robertson and Bruce, 2002; Yue et al., 2008; Huang et al., 2009). Note that extending the voltage cutoff to $2.0 \mathrm{~V}$ resulted in higher capacity $\left(157.5,168.3\right.$ and $121.2 \mathrm{mAh} \mathrm{g}^{-1}$ for samples annealed at 550,650 and $\left.750^{\circ} \mathrm{C}\right)$; however, the capacities decayed more quickly.

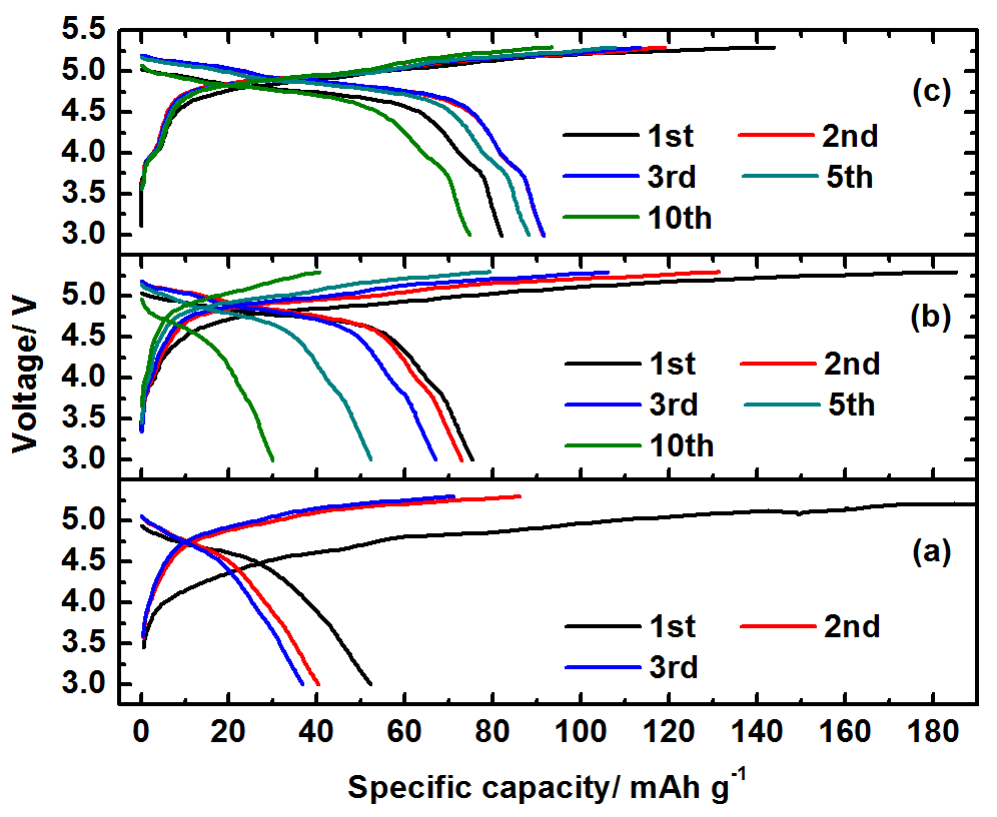

Fig. 7. Charge/discharge curves of samples obtained annealing the precursors in the presence of $1.35 \mathrm{M} \mathrm{LiOH}$ at (a) 550,650 and $750^{\circ} \mathrm{C}$

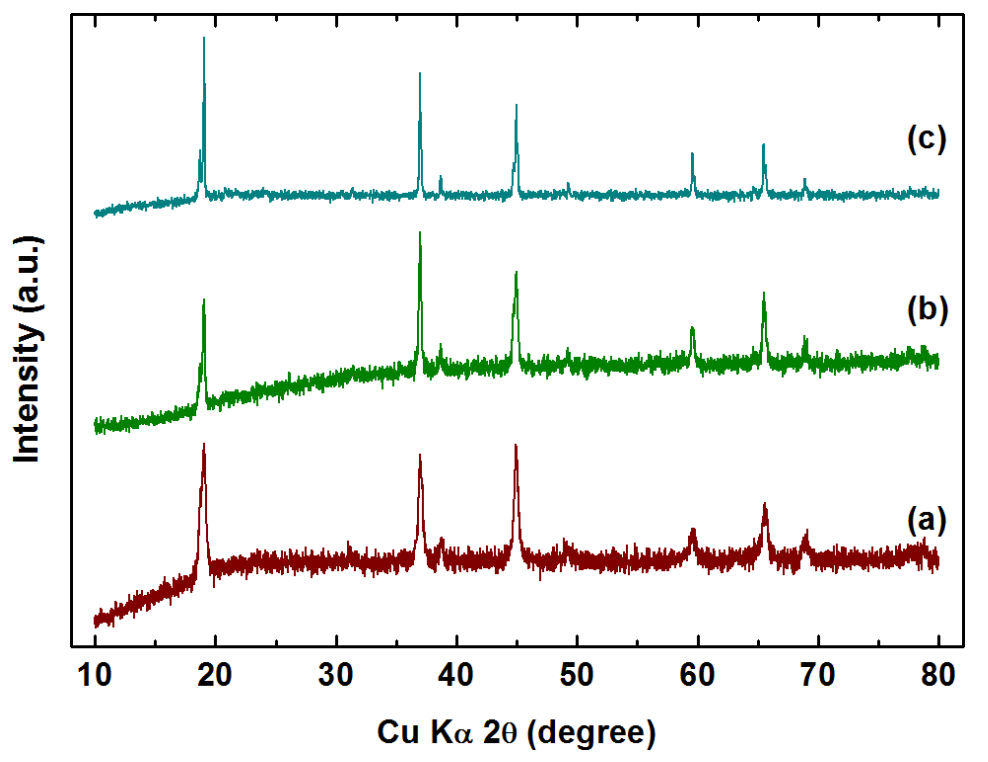




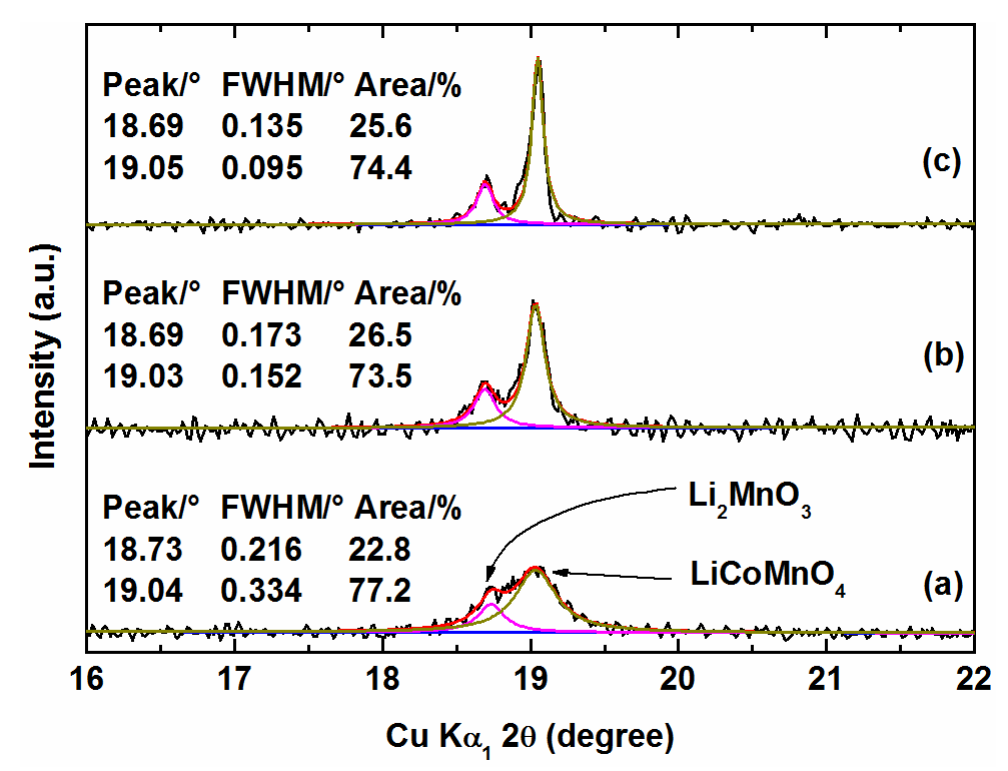

Fig. 8. XRD patterns of samples obtained in the presence of $1.5 \mathrm{M} \mathrm{LiOH}$ annealed at (a) 550 , (b) 650 and (c) $750^{\circ} \mathrm{C}$. The enlarged patterns between 18 and $22^{\circ}$ were shown at the bottom, where peak fitting was performed after striping $\mathrm{K \alpha}_{2}$

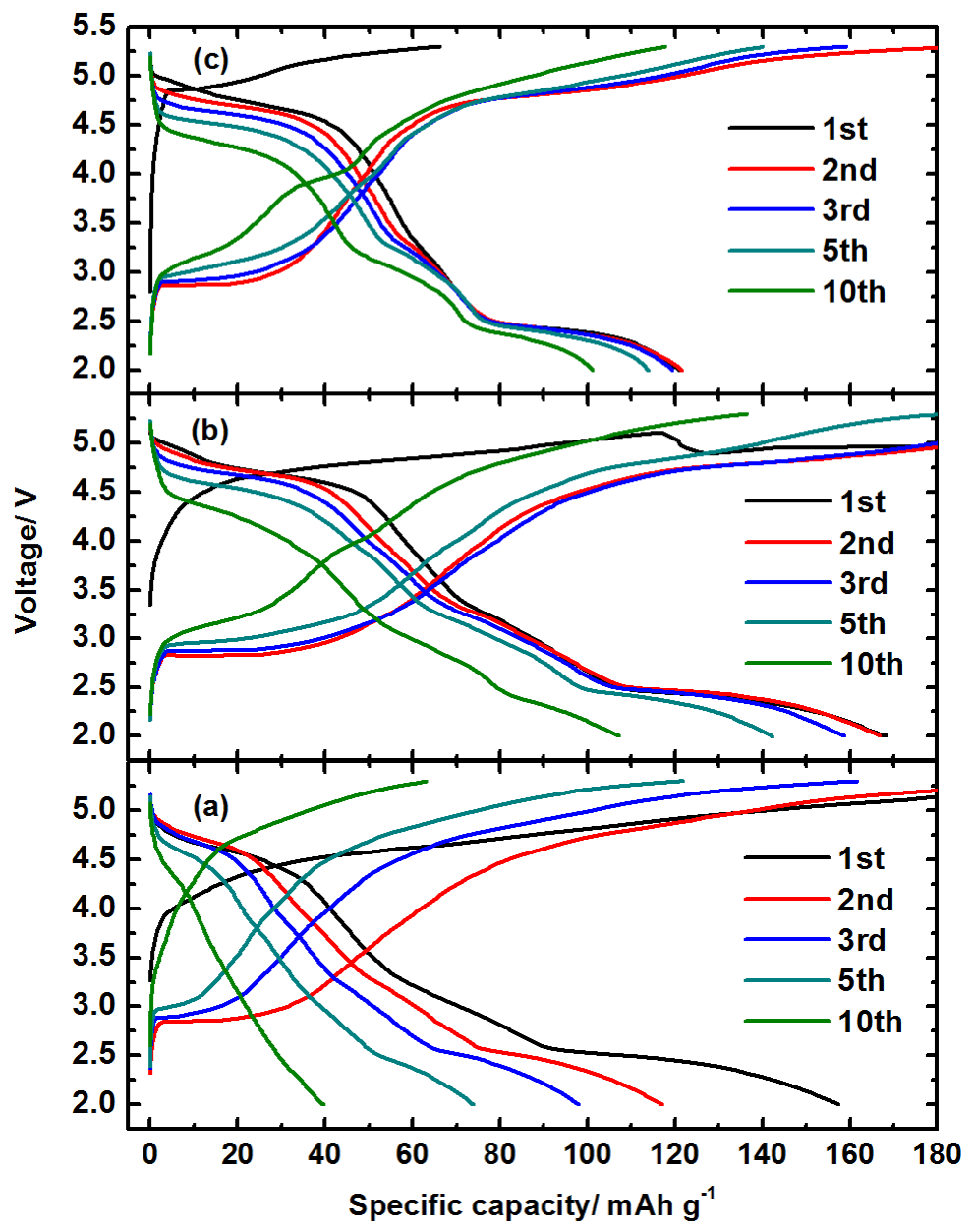

Fig. 9. Charge/discharge curves of samples obtained in the presence of $1.5 \mathrm{M} \mathrm{LiOH}$ annealed at (a) 550 , (b) 650 and (c) $750^{\circ} \mathrm{C}$ 
Finally we can conclude that the synthesis of $\mathrm{LiCoMnO}_{4}$ is very sensitive to the concentration of $\mathrm{LiOH}$ employed during hydrothermal reaction. We also noticed that it is very sensitive to $\mathrm{LiOH}$ and $\mathrm{NaOH}$ during hydrothermal preparations of $\mathrm{LiNi}_{0.5} \mathrm{Mn}_{1.5} \mathrm{O}_{4}$ (Huang et al., 2011) and $\gamma-\mathrm{MnO}_{2}$ (Lv et al., 2009), respectively. Therefore, it is worthy of note that a desired hydrothermal product may be obtained only in a narrow range of alkaline concentration.

\section{Conclusion}

$\mathrm{LiCoMnO}_{4}$ materials were synthesized via a hydrothermal approach followed by a post-annealing process. The concentration of $\mathrm{LiOH}$ significantly affects the hydrothermal precursors and the final annealed samples. At relatively low $\mathrm{LiOH}$ concentration (0.9-1.1 $\mathrm{M})$, the as-prepared hydrothermal precursors consist of $\mathrm{LiMn}_{2} \mathrm{O}_{4}$ as a major phase with $\mathrm{Co}_{3} \mathrm{O}_{4}$ and $\mathrm{Mn}_{3} \mathrm{O}_{4}$ as impurity phases. $1.2-1.35 \mathrm{M} \mathrm{LiOH}$ is the suitable condition for the formation of spinel phases while too high concentration of $\mathrm{LiOH}$ such as $1.5 \mathrm{M}$ results in the development of $\mathrm{Li}_{2} \mathrm{MnO}_{3}$.

However, without post-annealing process, the highest contents of $\mathrm{LiCoMnO}_{4}$ in the hydrothermal products are still less than $50 \%$ (e.g., in the case of 1.2-1.35 M $\mathrm{LiOH}$ ); in contrast, after annealing the hydrothermal precursors, the $\mathrm{LiCoMnO}_{4}$ contents in the as-obtained samples improved significantly. The annealing temperature also highly influences the structures and electrochemical performance of the final samples. In general, a higher annealing temperature results in a better crystallinity of the final product. However, the effect of the annealing temperature on the $\mathrm{LiCoMnO}_{4}$ content and electrochemical performance is cooperative with the $\mathrm{LiOH}$ concentration for its hydrothermal precursor. As a result, the optimized conditions are 1.35-1.4 $\mathrm{M} \mathrm{LiOH}$ for hydrothermal precursors and $750^{\circ} \mathrm{C}$ for the postannealing temperature. For example, the as-prepared sample in the presence of $1.35 \mathrm{M} \mathrm{LiOH}$, after annealed at $750^{\circ} \mathrm{C}$, delivered a capacity of $91.6 \mathrm{mAh} \mathrm{g}^{-1}$ with 79.5 $\mathrm{mAh} \mathrm{g}^{-1}$ located at above $4.2 \mathrm{~V}$.

\section{Funding Information}

This work is supported by Science and Technology Project from the Educational Commission of Fujian Province, China (Grant no. JA10072), Grant for Distinguish Young Scholar in Universities of Fujian Province, China (no. JA11040) and Science Foundation of Fujian Province, China (Grant no. 2011J05021). Y.Y. gratefully acknowledges the financial support from the National Basic Research Program of China (973 Program) (Grant no. 2007CB209702) and the National Natural Science Foundation of China Grants (Nos.
20473060, 29925310 and 20021002). Y.R. thanks Creative Experiments Project for Undergraduate Students of Fujian Province, China (no. Fjnu2011-022).

\section{Author's Contributions}

X.K.H., Q.S.T. and Y.Y conceived the idea. X.K.H. designed the experiments. M.L.Y., M.L., Y.R. carried out the material synthesis and characterization. X.K.H., Q.S.T. and Y.Y supervised all experimental design, tests and analyses and co-wrote the paper. All authors discussed the results and commented on the manuscript.

\section{Ethics}

These authors have no ethical issues that may arise after the publication of this manuscript.

\section{References}

Abouimrane, A., I. Belharouak and K. Amine, 2009. Sulfone-based electrolytes for high-voltage Li-ion batteries. Electrochem. Commun., 11: 1073-1076. DOI: 10.1016/j.elecom.2009.03.020

Abouimrane, A., S.A. Odom, H. Tavassol, M.V. Schulmerich and H.M. Wu et al., 2013. 3Hexylthiophene as a stabilizing additive for high voltage cathodes in lithium-ion batteries. J. Electrochem. Soc., 160: A268-A271.

DOI: $10.1149 / 2.039302 \mathrm{jes}$

Cabana, J., M. Casas-Cabanas, F.O. Omenya, N.A. Chernova and D. Zeng et al., 2012. Composition-structure relationships in the $\mathrm{Li}$-ion battery electrode material $\mathrm{LiNi}_{0.5} \mathrm{Mn}_{1.5} \mathrm{O}_{4}$. Chem. Mater., 24: 2952-2964. DOI: 10.1021/cm301148d

Hu, M., Y. Tian, L. Su, J. Wei and Z. Zhou, 2013. Preparation and Ni-doping effect of nanosized truncated octahedral $\mathrm{LiCoMnO}_{4}$ as cathode materials for $5 \mathrm{~V}$ li-ion batteries. ACS Applied Mater Interfaces, 5: 12185-12189. DOI: 10.1021/am404250k

Hu, M., Y. Tian, J.P. Wei, D.G. Wang and Z. Zhou, 2014. Porous hollow $\mathrm{LiCoMnO}_{4}$ microspheres as cathode materials for $5 \mathrm{~V}$ lithium ion batteries. J. Power Sources, 247: 794-798.

DOI: 10.1016/j.jpowsour.2013.09.038

Huang, X.K., M. Lin, Q.S. Tong, X.H. Li and Y. Ruan et al., 2012. Synthesis of LiCoMnO4 via a sol-gel method and its application in high power $\mathrm{LiCoMnO}_{4} / \mathrm{Li}_{4} \mathrm{Ti}_{5} \mathrm{O}_{12}$ lithium-ion batteries. J. Power Sources, 202: 352-356.

DOI: 10.1016/j.jpowsour.2011.11.028

Huang, X.K., Q.S. Zhang, H.T. Chang, J.L. Gan and H.J. Yue et al., 2009. Hydrothermal synthesis of nanosized $\mathrm{LiMnO}_{2}-\mathrm{Li}_{2} \mathrm{MnO}_{3}$ compounds and their electrochemical performances. J. Electrochem. Soc., 156: A162-A168. DOI: 10.1149/1.3054397 
Huang, X.K., Q.S. Zhang, J.L. Gan, H.T. Chang and Y. Yang, 2011. Hydrothermal synthesis of a nanosized $\mathrm{LiNi}_{0.5} \mathrm{Mn}_{1.5} \mathrm{O}_{4}$ cathode material for high power lithium-ion batteries. J. Electrochem. Soc., 158: A139-A145. DOI: 10.1149/1.3521292

Kawai, H., M. Nagata, H. Kageyama, H. Tukamoto and A.R. West, 1999. $5 \mathrm{~V}$ lithium cathodes based on spinel solid solutions $\mathrm{Li}_{2} \mathrm{Co}_{1+\mathrm{X}} \mathrm{Mn}_{3-\mathrm{X}} \mathrm{O}_{8}:-1<=\mathrm{X}<=$ 1. Electrochim. Acta, 45: 315-327. DOI: 10.1016/S0013-4686(99)00213-3

Kawai, H., M. Nagata, H. Tukamoto and A.R. West, 1998. A new lithium cathode $\mathrm{LiCoMnO}_{4}$ : Toward practical $5 \mathrm{~V}$ lithium batteries. Electroche. Solid State Lett., 1: 212-214. DOI: 10.1149/1.1390688

Kuwata, N., S. Kudo, Y. Matsuda and J. Kawamura, 2014. Fabrication of thin-film lithium batteries with 5-V-class $\mathrm{LiCoMnO}_{4}$ cathodes. Solid State Ion., 262: 165-169. DOI: 10.1016/j.ssi.2013.09.054

Lee, H., S. Choi, S. Choi, H.J. Kim and Y. Choi et al., 2007. SEI layer-forming additives for $\mathrm{LiNi}_{0.5} \mathrm{Mn}_{1.5} \mathrm{O}_{4} /$ graphite $5 \mathrm{VLi}$-ion batteries. Electrochem. Commun., 9: 801-806. DOI: 10.1016/j.elecom.2006.11.008

Li, D.C., A. Ito, K. Kobayakawa, H. Noguchi and Y. Sato, 2007. Electrochemical characteristics of $\mathrm{LiNi}_{0.5} \mathrm{Mn}_{1.5} \mathrm{O}_{4}$ prepared by spray drying and postannealing. Electrochim. Acta, 52: 1919-1924. DOI: 10.1016/j.electacta.2006.07.056

Liu, D., J. Hamel-Paquet, J. Trottier, F. Barray and V. Gariepy et al., 2012. Synthesis of pure phase disordered $\mathrm{LiMn}_{1.45} \mathrm{Cr}_{0.1} \mathrm{Ni}_{0.45} \mathrm{O}_{4}$ by a post-annealing method. J. Power Sources, 217: 400-406.

DOI: 10.1016/j.jpowsour.2012.06.063

Lv, D., X. Huang, H. Yue and Y. Yang, 2009. Sodiumion-assisted hydrothermal synthesis of $\gamma-\mathrm{MnO}_{2}$ and its electrochemical performance. J. Electrochem. Soc., 156: A911-A911. DOI: 10.1149/1.3206586

Mao, J., K.H. Dai and Y.C. Zhai, 2012. Electrochemical studies of spinel $\mathrm{LiNi}_{0.5} \mathrm{Mn}_{1.5} \mathrm{O}_{4}$ cathodes with different particle morphologies. Electrochim. Acta, 63: 381-390. DOI: 10.1016/j.electacta.2011.12.129

Markevich, E., V. Baranchugov and D. Aurbach, 2006. On the possibility of using ionic liquids as electrolyte solutions for rechargeable $5 \mathrm{~V} \mathrm{Li}$ ion batteries. Electrochem. Commun., 8: 1331-1334. DOI: 10.1016/j.elecom.2006.06.002
Robertson, A.D. and P.G. Bruce, 2002. The origin of electrochemical activity in $\mathrm{Li}_{2} \mathrm{MnO}_{3}$. Chem. Commun. (Camb), 7: 2790-2791. DOI: $10.1039 / \mathrm{b} 207945 \mathrm{c}$

Santhanam, R. and B. Rambabu, 2010. Research progress in high voltage spinel $\mathrm{LiNi}_{0.5} \mathrm{Mn}_{1.5} \mathrm{O}_{4}$ material. J. Power Sources, 195: 5442-5451. DOI: 10.1016/j.jpowsour.2010.03.067

Shin, D.W., C.A. Bridges, A. Huq, M.P. Paranthaman and A. Manthiram, 2012. Role of cation ordering and surface segregation in high-voltage spinel $\mathrm{LiMn}_{1.5} \mathrm{Ni}_{0.5-\mathrm{x}} \mathrm{M}_{\mathrm{x}} \mathrm{O}_{4}(\mathrm{M}=\mathrm{Cr}$, Fe and $\mathrm{Ga})$ cathodes for lithium-ion batteries. Chem. Mater., 24: 3720-3731. DOI: $10.1021 / \mathrm{cm} 301844 \mathrm{w}$

Xu, M.Q., Y.L. Liu, B. Li, W.S. Li and X.P. Li et al., 2012. Tris (pentafluorophenyl) phosphine: An electrolyte additive for high voltage Li-ion batteries. Electrochem. Commun., 18: 123-126. DOI: 10.1016/j.elecom.2012.02.037

Yang, T.Y., N.Q. Zhang, Y. Lang and K.N. Sun, 2011. Enhanced rate performance of carbon-coated $\mathrm{LiNi}_{0.5} \mathrm{Mn}_{1.5} \mathrm{O}_{4}$ cathode material for lithium ion batteries. Electrochim. Acta, 56: 4058-4064. DOI: $10.1016 /$ j.electacta.2010.12.109

Yi, T.F. and X.G. Hu, 2007. Preparation and characterization of sub-micro $\mathrm{LiNi}_{0.5-\mathrm{x}} \mathrm{Mn}_{1.5+\mathrm{x}} \mathrm{O}_{4}$ for $5 \mathrm{~V}$ cathode materials synthesized by an ultrasonicassisted co-precipitation method. J. Power Sources, 167: 185-191. DOI: 10.1016/j.jpowsour.2007.02.003

Yue, H., X. Huang, D. Lv and Y. Yang, 2008. Hydrothermal synthesis and electrochemical performance of $\mathrm{Li}_{1.59} \mathrm{H}_{0.41} \mathrm{MnO}_{3}$ as a cathode material for lithium-ion battery. Electrochem. SolidState Lett., 11: A163-A163. DOI: $10.1149 / 1.2955862$

Zhong, G.B., Y.Y. Wang, Z.C. Zhang and C.H. Chen, 2011. Effects of $\mathrm{Al}$ substitution for $\mathrm{Ni}$ and $\mathrm{Mn}$ on the electrochemical properties of $\mathrm{LiNi}_{0.5} \mathrm{Mn}_{1.5} \mathrm{O}_{4}$. Electrochim. Acta, 56: 6554-6561. DOI: $10.1016 /$ j.electacta.2011.03.093 